\title{
A Comprehensive Overview of Forensic Entomology
}

\author{
Manisha A. Sardar, Sanpreet S. Sachdev*, Sonali Kadam, Tabita J. Chettiankandy, Sarang Sonawane, Jagdish V. Tupkari \\ Department of Oral Pathology and Microbiology,Government Dental College and Hospital P D' Mello Road, Fort, Mumbai - 400001.
}

\begin{abstract}
Arthropods comprise the most ubiquitous species globally that play a key role in the decomposition process of a corpse. The entomological analysis of species commonly associated with carrion can provide valuable insights in investigations which forms the basis of Forensic Entomology. Since historical times, entomological data has aided in resolving numerous medico-criminal cases. Estimation of post-mortem interval by careful analysis of insect fauna associated with a decaying corpse is the most prominent application of Forensic Entomology. However, the conditions surrounding a decomposing corpse are not always optimum, and the rate of decomposition is influenced by multiple factors that need to be considered by forensic entomologists. The present article provides a comprehensive overview of the field of Forensic Entomology, its various applications, limitations and advances through time.
\end{abstract}

Keywords: Autopsy, Diptera, Forensic Toxicology, Insecta, Post-mortem interval. Int J Eth Trauma Victimology (2021). DOI: 10.18099/ijetv.v7i01.5

\section{INTRODUCTION}

$\mathrm{H}^{\prime}$ uman and animal cadavers serve as a source of nutrients and breeding grounds for insects in general, of which, about 400 species have been identified. ${ }^{1}$ Of these, Arthropoda comprises the most extensive, ubiquitous biological phylum of our planet, outnumbering even the plants. They thrive and breed in environments such as corpses thereby playing a key role in their decomposition. ${ }^{2}$ Arthropods such as Flies (Diptera), beetles (Coleoptera), mites (Arachnida), lice (Isopoda), harvestmen (Opiliones) have been found to be associated with corpses; varying species in larval, pupal, and adult stages have been demonstrated in carrion varying in size and stage of development, depending upon their biological preferences, the extent of the decomposition process and geographical location. ${ }^{3}$

Careful analysis of entomological findings pertaining to the insects dwelling in carrion can aid in discovering pieces of information critical for investigation concerned with the death of an individual that would otherwise be lost in the absence of awareness on the part of forensic personnel. ${ }^{4}$ The study and application of such entomological data with other forensic investigations in suspected criminal or medicolegal cases and civil proceedings have been termed "Forensic Entomology". 5 In other words, Forensic Entomology bridges the science of entomology with forensic medicine and law. The applications of Forensic Entomology was segregated into three categories by Lord \& Stevenson in $1986,{ }^{6}$ which are illustrated in [Figure 1].

The study of various stages and species of insects demonstrated in carrion along various stages of decomposition, and its application in discerning the circumstances related to death and estimating the time elapsed constitutes the essence of medico-criminal Forensic Entomology. ${ }^{7}$ Unlike the estimated post-mortem interval (PMI) determined by means of a medical examination which is limited to not more than
Corresponding Author: Dr. Sanpreet Singh Sachdev, Department of Oral Pathology,Government Dental College and Hospital P D' Mello Road, Fort, Mumbai -400001., e-mail: sunpreetss@yahoo.in How to cite this article: Sachdev SS. A Comprehensive Overview of Forensic Entomology. Int J Eth Trauma Victimology. 2021;7(1):19-28.

Source of support: Nil

Conflict of interest: None

Received:27/03/2021;

Accepted:24/05/2021;

Received in revised form: 20/05/2021; Published: 25/06/2021

two days, entomological analysis has been demonstrated as a more reliable method in providing more precise data over long periods of time such as seasons or even years. ${ }^{7,8}$

The present article provides a brief account of the ancient yet young field of Forensic Entomology, its various applications, limitations, and advances through time.

\section{Historical account of Forensic Entomology}

The earliest existing record of application of forensic entomology in literature has been depicted in a Chinese book

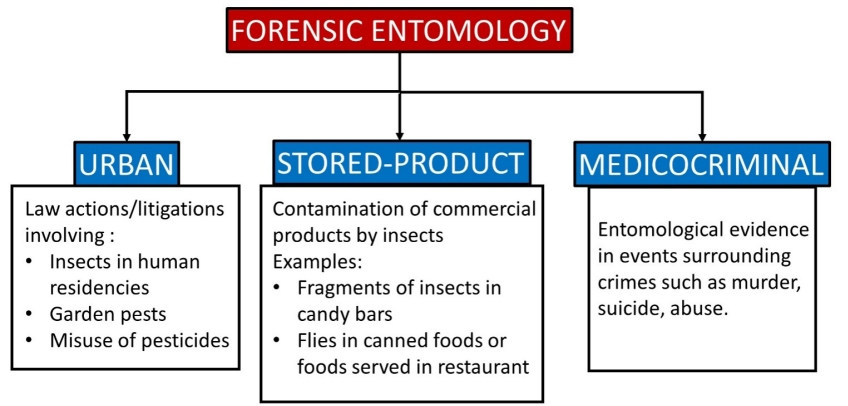

Figure 1: Categories of applications of Forensic Entomology 
authored by Sung Tzu pertaining of criminal investigations entitled - "The Washing Away of Wrongs" in which flies were attracted to imperceptible bloodstains on a murder weapon. ${ }^{9}$ Maggots on corpses were illustrated in the $15^{\text {th }}$ century on woodcuts - "Dances of the Death" and in the 16th-century ivory carvings - "Skeleton in the Tumba" terminology

Necrophagous insects comprising of flies, beetles and other taxa were enlisted in the former half of $19^{\text {th }}$ century. ${ }^{10}$ French Doctor Bergeret provided the foremost application of entomological analysis for PMI in 1855 wherein the age of a skeletonized corpse of a child discovered behind a chimney was estimated by blowfly pupae and larval moths. ${ }^{11}$ The utility of insects for the estimation of PMI and various problems associated with the process were further elaborated by Krahmer in 1857. ${ }^{12}$ The first systematic research in Forensic Entomology was first reported in 1881 wherein Phorid flies and beetles were taxonomically identified from exhumated bodies in Saxonia ${ }^{13}$ and a similar report from exhumated bodies were provided by Hofmann in $1886 .{ }^{14}$ Through the generous efforts of Yovanovitch and Megnin across multiple publications from 1883-1896, the sequence of insect succession on carrion was delineated, which served as the foundation of modern-day science of Forensic Entomology. ${ }^{4}$ Towards the end of $19^{\text {th }}$ century, up to eight successional waves of insects infesting on carrion were described in a comprehensive book pertaining to entomological science entitled 'La Faune des Cadavres' which is undoubtedly the greatest contribution to the field by Megnin. ${ }^{15}$ Consequently, the published in-depth knowledge about general fauna present on mummified or decayed corpses attracted interest of researchers towards the subject and the mould Endoconidium megnini was named in honour of the researcher. ${ }^{16}$

\section{The Process of Decomposition}

The sequential setting in of post-mortem effects in a fresh corpse such as stiffness (rigor) followed by stagnation of blood (livor), subsequent reduction of body temperature (algor), aid a pathologist in determining the time elapsed since death with reasonable accuracy in the early post-mortem period (1-3 days) ${ }^{17}$ These changes in the corpse are followed by its decomposition, thereby limiting the utility of thanatological evidence in later stages. Although the process of decomposition of a corpse is continuous, it would be pertinent to delineate its various sequential stages so as to make it understandable more easily. The overall process of decomposition can be divided into two primary stages, this first exhibiting bloating and active decay of carrion by maggots whereas the latter half is characterized by loss of seepage fluids and dispersal of postfeeding maggots characterizing advanced decay of prolonged duration ultimately resulting in dry or skeletal remains. ${ }^{18}$ A minimum period of three years is expected between the death and last stage, wherein only the debris remains. ${ }^{5}$ The decomposition sequence can be analyzed to reliably estimate the time of death over prolonged periods of time (Table 1). However, the accuracy of estimation is generally inversely

Table 1: Duration of various stages of post-mortem decomposition of the corpse in different environments

\begin{tabular}{|c|c|c|}
\hline Exposed corpse & Buried corpse & Submerged corpse \\
\hline $\begin{array}{l}\text { Initial decay ( } 0-2 \text { days) } \\
\text { Appears fresh but is decaying internally } \\
\text { due to the presence of antemortem } \\
\text { bacteria and nematodes }\end{array}$ & $\begin{array}{l}\text { Fresh ( } 3 \text { days) } \\
\text { The period from death to initial bloating. Ants } \\
\text { feed actively on moist parts. }\end{array}$ & $\begin{array}{l}\text { Submerged Fresh ( } 1-2 \text { days) } \\
\text { Only hydrophilid beetles appear on carcass }\end{array}$ \\
\hline $\begin{array}{l}\text { Putrefaction ( } 2-12 \text { days) } \\
\text { Swollen by gases produced by internal } \\
\text { decay accompanied with odour }\end{array}$ & $\begin{array}{l}\text { Bloating stage ( } 3-7 \text { days) } \\
\text { Ants and Diptera predominate }\end{array}$ & $\begin{array}{l}\text { Early floating ( } 1-2 \text { days) } \\
\text { Blowflies and fruit-flies feed on floating } \\
\text { abdomen of corpse } \\
\text { Pronounced decay odour and gas bubbles } \\
\text { evident on the water surface }\end{array}$ \\
\hline $\begin{array}{l}\text { Black putrefaction ( } 12-20 \text { days) } \\
\text { Creamy flesh with black exposed parts. } \\
\text { Strong odour owing to escaping gases }\end{array}$ & $\begin{array}{l}\text { Deflation ( } 7 \text { to } 30 \text { days) } \\
\text { - Strong odour owing to deflation of corpse } \\
\text { - Parasites such as Hymenoptera appear } \\
\text { - Colonies of fungi and bacteria get established } \\
\text { on clumped fluids }\end{array}$ & $\begin{array}{l}\text { Floating decay ( } 3-7 \text { days) } \\
\text { Blowfly eggs hatch on } 3^{\text {rd }} \text { day } \\
\text { Larvae gain access through multiple holes } \\
\text { created by maggot activity } \\
\text { Staphylinid and hysterid beetles abundant. }\end{array}$ \\
\hline $\begin{array}{l}\text { Butyric fermentation ( } 21-40 \text { days) } \\
\text { Carcass begins to dry out. Flesh has } \\
\text { cheesy odour. The ventral surface of } \\
\text { the body becomes mouldy due to } \\
\text { fermentation }\end{array}$ & $\begin{array}{l}\text { Disintegration: ( } 30-60 \text { days) } \\
\text { Colonies of fungi and bacteria cover the carcass } \\
\text { Mites (Caloglyphus) form the primary scavenger } \\
\text { group }\end{array}$ & $\begin{array}{l}\text { Bloated deterioration } \\
\text { As the exposed surface reduces, maggots and } \\
\text { beetles are forced into the water } \\
\text { Maggots migrate by the } 7^{\text {th }} \text { day since exposed } \\
\text { tissue is exhausted }\end{array}$ \\
\hline \multirow[t]{2}{*}{$\begin{array}{l}\text { Dry decay (post } 40 \text { days) } \\
\text { Carcass almost dries out. A slow rate of } \\
\text { decay }\end{array}$} & $\begin{array}{l}\text { Skeletonization: (post } 60 \text {-days) } \\
\text { The carcass is predominated by ants, mites and } \\
\text { flies. Spiders, centipedes and millipedes also } \\
\text { appear. }\end{array}$ & $\begin{array}{l}\text { Floating remains ( } 4-14 \text { days) } \\
\text { Few maggots, flies and beetles feed on corpse. } \\
\text { Many dead maggots on the water surface. } \\
\text { Ends when the corpse sinks. }\end{array}$ \\
\hline & & $\begin{array}{l}\text { Sunken remains ( } 10-30 \text { days) } \\
\text { Decomposition of the corpse is completed } \\
\text { by bacteria and fungi; only bones and a small } \\
\text { number of flesh remains }\end{array}$ \\
\hline
\end{tabular}


proportional to the time elapsed since death making it more accurate in the early weeks. ${ }^{19}$

\section{Insect Succession}

Carrion progressing along the certain stages of decomposition tends to attract varying arrays of insects in a predictable chronological sequence called 'insect succession'. ${ }^{15}$ Recognition of the existing fauna would reveal the stage of decomposition and, subsequently, the time elapsed since death. The insects present on carrion the environment has been segregated into four categories based on their ecological role ${ }^{20,21}$ and are summarized in Table 2.

Beneath the cadaver, a seepage zone usually exists that tends to harbor a complex community of insects including mites and other arthropods that are collectively categorized as 'cryptozoics'. ${ }^{23}$ Unless a forensic expert with sound knowledge of the entomological evidence is present at the scene of the crime, such rich zones of evidence tend to be missed out during investigation while the entire focus is laid upon collection of specimens from the corpse only. ${ }^{25}$ Not much is known about their potential in the field of Forensic Entomology, thereby highlighting the need to conduct more research.

Several parameters influence the composition of a community of insects associated with carrion such as a season, geographical location, habitat. In cases involving the transport of a corpse from one type of habitat to another, variable succession patterns could provide valuable insight regarding the season of the year or location of death. ${ }^{7}$

The insect succession expressed on carrion may vary depending upon several other parameters such as habitat or seasonal climate. Careful identification of these patterns can provide an important insight into an investigation, such as identifying the season of the year at the time of death or whether the corpse was transported post-mortem after first colonization. ${ }^{7}$

Table 2: Categories of insects identified on a decomposing carrion

\begin{tabular}{|c|c|c|c|}
\hline SrNo. & Category & Description & Examples \\
\hline 1. & Necrophages[15,22] & $\begin{array}{l}\text { - Species that primarily feed on carrion. } \\
\text { - Appear in early stages of decomposition } \\
\text { - Age determination of these insects is most commonly } \\
\text { correlated to obtain an estimated PMI }\end{array}$ & $\begin{array}{l}\text { Diptera (flies): } \\
\text { Calliphoridae (blowflies) } \\
\text { Sarcophagids (flesh flies) } \\
\text { Coleoptera (beetles): } \\
\text { Silphidae (carrion beetles) } \\
\text { Dermestidae(skin beetles) }\end{array}$ \\
\hline 2. & $\begin{array}{l}\text { Omnivores } \\
{[20]}\end{array}$ & $\begin{array}{l}\text { - Feed on both the carrion and associated fauna } \\
\text { - May deplete necrophages, thereby retarding } \\
\text { decomposition } \\
\text { - At present, limited potential for the provision of forensic } \\
\text { information is known }\end{array}$ & $\begin{array}{l}\text { Various species of ants, wasps, and } \\
\text { beetles }\end{array}$ \\
\hline 3. & $\begin{array}{l}\text { Predators and Parasites } \\
{[21,23]}\end{array}$ & $\begin{array}{l}\text { - Parasitize or devour immature flies, mites, nematodes, } \\
\text { and other insects } \\
\text { - Some species are necrophagous in the early } \\
\text { developmental stages that become predaceous later [24] } \\
\text { - May eliminate competing species } \\
\text { - Their role in the provision of forensic information is } \\
\text { second to the necrophages. }\end{array}$ & $\begin{array}{l}\text { Hymenoptera, Uropodidae, } \\
\text { Macrochelidae, Parasitidae, } \\
\text { Parholaspidae }\end{array}$ \\
\hline 4. & $\begin{array}{l}\text { Incidentals or adventive } \\
\text { species }[15,23]\end{array}$ & $\begin{array}{l}\text { - Use the carrion as an extension of their natural habitat. } \\
\text { - Species-specific to the habitat of the scene of crime }\end{array}$ & $\begin{array}{l}\text { Spiders, Centipedes, pill bugs, and } \\
\text { Springtails }\end{array}$ \\
\hline
\end{tabular}

\section{Blowflies}

Most frequently in cases where the corpse has access, various species of Calliphoridae (blowflies) appear on the cadaver and oviposit within the first few minutes to hours following death. ${ }^{26}$ Thus, these earliest appearing arthropods initiate a biological clock whereby staging the developing progeny most frequently forms the basis of PMI estimation in forensic odontology. The life cycle of blowflies ${ }^{27}$ commences with the hatching of larvae from the eggs (commonly referred to as 'maggots') that are necrophagic. Following adequate feeding, the larvae need to shed their cuticle (moult) in order to enable further growth which is termed as 'ecdysis, which results in the development of larval instar. The process occurs twice in the life cycle of a blowfly following which they migrate to a safe area and enter the post-feeding puparium stage comprising of the hardened cuticle of the third larval instar. The safe area could refer to stones or leaves in outdoor crime scenes and furniture or doors indoors. It is, thus, essential to extend the examination of carrion to its environment as well. ${ }^{7}$ Ultimately, the adult flies emerge, marking the completion of metamorphosis. The overall process is depicted in Figure 2.

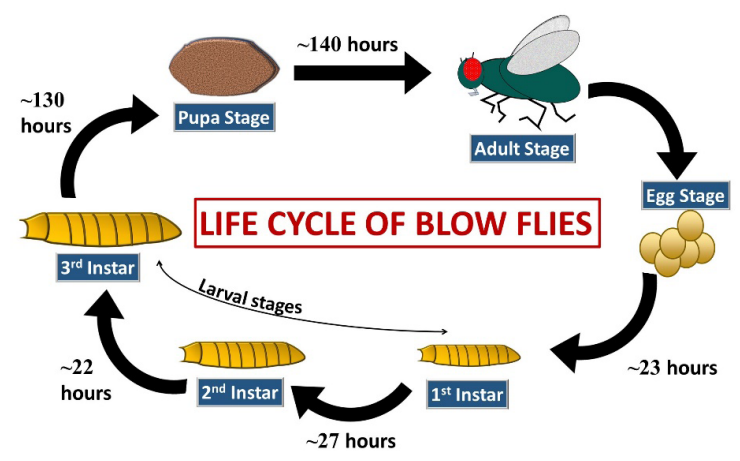

Figure 2: Life cycle of blowflies with approximate duration of each stage 
The time elapsed since hatching of the blowfly egg can be determined based on maggot weight and temperature of the carrion niche. ${ }^{28,29}$ However, the larval size may not always be dependable as it may change significantly during the process of preservation depending upon its duration and the type of preservative used. ${ }^{30}$ Furthermore, the oviposition activity of blowflies generally peaks during the afternoon since the arthropods are inactive at night. ${ }^{31}$ Thus, the possibility that a corpse infested by recently hatched maggots discovered in the afternoon could have been deposited there in the late evening of the day prior to its discovery should not be overlooked during forensic investigations. Conversely, eggs detected on the corpse at night would infer that death would have occurred during the daytime.

\section{Methodology in Forensic Entomology}

\section{Collection of Specimens}

A forensic entomologist must be thoroughly versed with all the possible zones present in and around the crime scene that could contain entomological evidence to ensure that potential areas of forensic importance do not go unnoticed. Various sites for the collection of samples from the crime scene may include - natural orifices, wounds and clothing/wrapping material of the corpse, underlying seepage zones, nearby carpets and doorframes. In the case of indoor crime scenes, one must look in other rooms for any possible pieces of entomological evidence while collecting soil samples (10 $\mathrm{cm}$ depth) is recommended for outdoor crime scenes. The temperature of the body, crime scene, and environment must also be promptly noted. In addition, an attempt must be made to acquire local climatic data such as the daily range of temperature. It is recommended to preserve the specimens in $70-95 \%$ ethanal from a biosafety standpoint. ${ }^{32}$ The use of formalin should be avoided as it leads to loss of morphological and molecular preservation. A detailed guide for handling, preservation, and transport of entomological evidence in various stages was provided by Amendt et al. ${ }^{32}$

\section{Recommended Equipment for Forensic Entomology}

A forensic entomologist must be acquired beforehand with a toolbox comprising of certain essential equipment (Table 3) that would be required during a crime-scene investigation.

\section{Post-mortem Applications of Forensic Entomology}

\section{Determination of Post-Mortem Interval}

PMI is the interval of time that has elapsed between death and recovery of the body. ${ }^{32}$ Estimation of PMI is the most important application of Forensic Entomology in medicolegal cases. The possibility that the extent of decomposition of a corpse

Table 3: Recommended equipment for entomological forensic investigation

\begin{tabular}{|c|c|c|}
\hline Group & Equipment & Purpose \\
\hline \multirow{5}{*}{$\begin{array}{l}\text { 1. Documentation } \\
\text { equipment }\end{array}$} & Protocol sheets & Writing down details related to crime scene and specimens \\
\hline & Dark graphite pencil or pen with indelible ink & \\
\hline & Camera/Video recorder & Photographic documentation \\
\hline & $\begin{array}{l}\text { Standard measurement scale. Example: ABFO } \\
\text { scale no. } 2\end{array}$ & $\begin{array}{l}\text { To be used while photographing specimen to ensure quality and } \\
\text { identify distortion }\end{array}$ \\
\hline & Labels & For identification of specimens \\
\hline \multirow{5}{*}{$\begin{array}{l}\text { 2. Collection } \\
\text { equipment }\end{array}$} & Fine and coarse paintbrushes (moistened) & For collecting eggs \\
\hline & Spoons & For collecting maggots \\
\hline & Forceps (varying spring tensions and sizes) & $\begin{array}{l}\text { For collecting insects of corresponding stages } \\
\text { Fine - immature/fragile insects } \\
\text { Medium - adult insects }\end{array}$ \\
\hline & Shovel or trowel & $\begin{array}{l}\text { For a collection of soil and leaf-litter samples, including buried } \\
\text { larvae }\end{array}$ \\
\hline & Handheld insect capture net & For catching flying insects \\
\hline \multirow{2}{*}{$\begin{array}{l}\text { 3. Temperature } \\
\text { recording } \\
\text { equipment }\end{array}$} & Thermometer & $\begin{array}{l}\text { for measuring the body and ambient } \\
\text { temperatures, as well as the larval mass temperature }\end{array}$ \\
\hline & Temperature data logger & $\begin{array}{l}\text { Measurement of the temperature of crime-scene for a number of } \\
\text { days following the discovery of a dead body }\end{array}$ \\
\hline \multirow{6}{*}{$\begin{array}{l}\text { 4. Storage and } \\
\text { Transport }\end{array}$} & Tissue paper & For handling eggs and living larvae \\
\hline & Vials and storage boxes of different sizes & Preservation of collect insect specimens \\
\hline & Reusable ice packs in cooler bag & For storing living insect specimens \\
\hline & Ethanol (70-95\%) & For storage of dead specimens \\
\hline & Sticker, Sealing Wax, Tapes & Material for sealing the samples \\
\hline & Durable plastic or paper bags & $\begin{array}{l}\text { for storage of soil } \\
\text { samples and leaf litter specimens }\end{array}$ \\
\hline
\end{tabular}


could be calculated by means of entomological data subject to certain limitations was first suggested by Krahmer. ${ }^{12}$ The carrion in question would have a set of fauna associated with it from which the PMI can be estimated by two approaches depending on the extent of decomposition. Some flies such as $C$. vicina colonize the cadavers and oviposit as early as within only a few hours of death, while other species such as L. sericata may appear after 2 days and L. argyrostoma after 3-5 days [21]. In the earlier stages of decomposition, detection of deposited eggs of the respective species and developed in carrion have been confirmed to provide a PMI closest to the actual period ranging up to 10 days. ${ }^{33}$

Another approach to determining PMI would be applicable in cases of advanced stages of decomposition by means of observing the arthropod community present on the carrion and relating it to the expected insect successional pattern. ${ }^{18}$ Estimates of PMI up to 52 days have been successfully obtained by using the entomological succession approach, and with adequate data, it may be extrapolated to a much longer time interval. ${ }^{34}$ Both the approaches have demonstrated the possibility of exact assessment of the PMI of cadavers as long as the collection of insects was performed in a coordinated and standardized manner so as to avoid any loss of evidence. ${ }^{33}$

\section{Age Determination of Insects}

Besides observing the developmental stages of blowflies, the determination of the age of the oldest individual insects in a fauna can also aid in the derivation of the time elapsed since death, especially in cases of indoor investigations. Ageing the oldest insects on a body would provide the minimum time when the adult females of the species first gained access after death, referred to as 'minimum post-mortem interval.' ${ }^{32}$ Standard rules and guidelines dictate that the species must be correctly identified by means of reliable identification keys before proceeding with their age determination. ${ }^{32}$ Various methods have been employed to obtain the minimum duration of development for the oldest stage of insects present in a carrion fauna. Enumeration of cuticular bands that are added daily to the skeletal apodemes of blowflies could directly be employed in the calculation of their age. ${ }^{35}$ Another method for age estimation of flies involves measuring the pteridine levels in the eyes of adult screwworm flies, which is an excretory product stored in fresh or dried specimens following sequestration. ${ }^{36}$ However, the accuracy of minimum post-mortem interval provided by any method would be questionable since the developmental process of insects is dependent on multiple parameters such as available source of diet, diapause, competition amongst species and maggot generated heat. ${ }^{8,19}$ These factors can lead to false perception in each model of age estimation, and integral assessing the interactions between them makes the process even more complex analogous to a Gordian knot. ${ }^{37}$

The optimal temperature required for the development of an insect ranges between definite upper and lower values termed as 'upper developmental threshold' and 'lower developmental threshold', respectively. The threshold values are speciesspecific and vary between different life stages; temperatures beyond these values adversely affect the development of insects. ${ }^{32}$ Therefore, within the limits of the threshold values, an insect would require a specific amount of accumulated heat from the time of its oviposition to the time of its hatching which is assumed to have a linear relation to the rate of development. ${ }^{8}$ The approach of 'thermal summation' measures, by means of hand-held digital infrared thermometers, the thermal time i.e. the temperature value multiplied by time and is calculated in terms of acquired degree-hours (ADH) or acquired degreedays (ADD). ${ }^{38}$ Measurement of ADH or ADD can be extended to each developmental stage (egg, instar, pupa) requiring a specific number to complete their development. ${ }^{39}$

Recent advances in genetic research have demonstrated age dependency of genetic expression for several products in blowfly pupae. ${ }^{40}$ For example, an altered pattern of expression rates by three genes was utilized for the prediction of age in eggs of L. sericata in a study by Tarone et al. ${ }^{41}$

\section{Factors Affecting the Decay Rate of Carrion}

\section{Temperature}

Temperature, access by insects, and depth of burial were identified as the three most influential environmental factors in the rate of corpse decay in a study of 150 corpses. ${ }^{42}$ Decomposition of corpses proceeds most rapidly when the environmental temperatures are warm, positively correlated with a greater carrion insect population. ${ }^{43}$ After a year postburial, the degree of decomposition of bodies buried in the summer months is generally higher as compared to those interred in the cold winter period. ${ }^{44}$ The continuous feeding and metabolic activity by many maggots tend to generate a substantially higher temperature than the ambient one; the process is termed 'maggot mass effect'. ${ }^{29}$ The level of the heat generated may have species-specific effects, subsequently influencing the entire fauna present on the carrion. A study had demonstrated tolerance of higher temperature due to maggot mass by Chrysomya rufifacies but complete 'burning out' of Lucilia cuprina species population. ${ }^{45}$ The generated heat could also reduce the cooling effect of the mortuary refrigeration units prior to autopsy. ${ }^{19}$ It could also introduce a false perception in ADH calculations, thus, emphasizing the need for urgent forensic pathological examination of corpses that are heavily colonized by larval masses. ${ }^{46}$ The rate of temperature change in a corpse may also be affected by other conditions such as the amount of body fat, presence or absence of clothing, exposure of the corpse to sunlight, the velocity of wind, especially in case of outdoor deaths or submergence of a corpse in water. ${ }^{33}$ Researchers have reinforced Casper's rule stating that "At a tolerable similar average temperature, the degree of putrefaction present in a body lying in the open air for one week (month) corresponds to that found in a body after lying in the water for two weeks (months), or lying in the earth in the usual manner for eight weeks (or months)". ${ }^{47}$ 


\section{Exposure and Concealment}

Infestation of flies and subsequent oviposition first occurs at the orifices of the corpse. ${ }^{48}$ Besides naturally existing ones, the contrived orifices such as gaping wounds or stabbing serve as a rich source of nutrition for the maggots thereby attracting them in greater numbers consequently speeding up the process of decomposition..$^{42,48}$ The size of carcass also affects its attractiveness to insects wherein the Calliphoridae species tend to be attracted to those of larger size while some other necrophagous insects prefer to oviposit on smaller carcasses such as rodents or even snails. ${ }^{48}$ Thus, newly born infants that have a much smaller body size are not so prone to putrefaction owing to fewer microorganisms being present in their orifices having not breathed or swallowed food and tendency to be wrapped in absorbent materials which bars the access of insects to the body and also creates a dry environment. ${ }^{49}$ Burned or charred flesh also creates a similar dry environment that has been found to reduce the attractiveness of the corpse to blowflies. ${ }^{50}$ Restoration of moisture of a dried carcass to levels acceptable by the carrion feeders may occur in a rainy environment. ${ }^{51}$

Restricting the access of carrion insects to a body by wrapping in clothing or burying would obviously retard its decomposition rate. ${ }^{42}$ Blowfly invasion of the corpse can be delayed for up to several days if the corpse is wrapped in multiple layers of blankets. ${ }^{52}$ Most Diptera cannot colonize buried or concealed corpses; thus, a different composition of carrion-associated fauna comprising of Phoriade such as Megaselia scalaris can be expected in such cases. ${ }^{53,54}$ In case of an investigation pertaining to buried Indian remains, numerous empty fly pupal cases and scarabeid beetles but no adults were detected on the bodies indicating that the infestation must have occurred originally before burial when the bodies were exposed to air; correlation with the known values of time from insect succession models, a period of exposure of three weeks was determined and confirmed later. ${ }^{55}$

\section{Aquatic Environment}

The decomposition of a corpse in an aquatic environment is entirely different as compared to one exposed to air or buried in the land. Submergence of a corpse in water retard the decomposition process to a rate roughly half of that on land owing to restriction of access to common necrophages, reduced insect activity and a cooler environment. ${ }^{48}$ Roughly, six stages of decomposition in aquatic environment traversing from submerged fresh, floating decay to sunken remains have been described by Merrit and Wallace, although a definitive insect succession model comprising of sequential waves of colonization of a corpse in aquatic habitat has not been identified. ${ }^{56}$ Not much is known about the role of freshwater or marine arthropods in the decomposition of a corpse; however, those identified of forensic importance include Ephemeroptera (mayflies), Trichoptera (caddis flies) and Diptera (true flies). These insects utilize the carrion both as a food source and breeding site but are not obligatory macrophages. ${ }^{48}$ Therefore, their utility in estimation PMI is even more difficult since their appearance may vary according to the season and other conditions of the aquatic system.

Terrestrial arthropods can survive for a variable amount of time when the corpse is transferred to an aquatic environment. Simpson stated that "Fleas are drowned in twenty-four hours or so. If immersed for twelve hours they require about an hour for revival, and after eighteen to twenty hours' immersion, a period of some four to five hours. Body-lice usually die in twelve hours". ${ }^{57}$ Species such as Demodex can survive for a week in aquatic habitat and when such species can have a basis for estimating the PMI in cases wherein the bodies have been submerged in water for short periods of time. ${ }^{58} \mathrm{~A}$ similar case was reported wherein live terrestrial fly larvae were found on the body and trousers of a murdered corpse in a tank of seawater used for firefighting. The killer's confession confirmed that the victim was killed earlier and moved the body to a tank for only a short time where it was discovered; the fly pupae related to those on the body were also identified on the seat of vehicle used to transport the corpse.$^{59}$ Identification of larvae in submerged and floating corpses is difficult since the morphological distinctions are often lacking in the collected specimen. The possibility of DNA probe in identifying insects from their bodies or even fragmented parts in such cases. ${ }^{60}$

\section{Geographic Variation}

Different species of insects may be found associated with carrion in different areas such as rural or urban, some of which can be exclusive to a certain habitat. ${ }^{48}$ The species of blowflies with wide geographical distributions that are most commonly a part of forensic entomological investigations also exhibit intraspecific variations and microclimatic differences depending upon the geographical location. ${ }^{21,19}$ There is a growing concern amongst forensic entomologists as these differences in the biology of blowflies may reflect unstudied aspects that need to be emphasized and could have forensically important implications. Identification of species-specific to a certain habitat or an alteration in insect succession pattern could indicate post-mortem transport of a corpse.${ }^{61}$ Conversely, one should exercise caution when using data collected for a particular region or area for estimation of PMI. It would, therefore, be advantageous to have a forensic entomologist with local rearing experience of the specific insect in question.

The factors influencing the decomposition of the corpse is illustrated in [Figure 3].

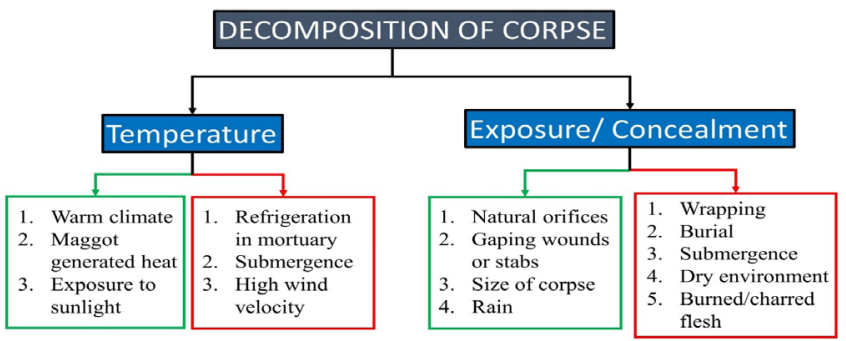

Figure 3: Factors influencing decomposition rate of corpses. Green boxes indicate factors accelerating the decomposition process; Red boxes indicate factors retarding the decomposition process. 


\section{Antemortem Applications of Forensic Entomology}

While most of the cases described above were centred around the determination of PMI on the basis of entomological data, entomological evidence can provide important insights regarding antemortem circumstances.

\section{Discerning Antemortem Circumstances of Death}

In one case of homicide, bites of chigger Eutrombicula belkini detected on both, crime-scene investigators and a suspect determined that the suspect had been at the scene of the crime earlier. ${ }^{62}$ However, drying of post-mortem ant bites can also give the impression of chemical or cigarette burns or frictional lesions ${ }^{63}$ while scattered stains of blood made by fleas may resemble those from traumatized blood vessels; ${ }^{64}$ these should be carefully considered while discerning antemortem scenario. Previous findings have suggested that $\mathrm{ABO}$ blood typing of the corpse is not affected by trail-marking contamination of ants and mites. ${ }^{65}$ Yet another case detailed the use of maggot development to determine the period of child neglect wherein maggots had developed in the faecal matter inside the diaper of a 16-month-old abandoned child and had also infested the genital and rectal areas. ${ }^{66}$

\section{Detection of Antemortem Drugs and Toxins}

Detection of drugs such as phenobarbital, benzodiazepines, and tricyclic antidepressants in maggots developing on a corpse derived the interest of researchers towards the potential use of entomological analysis for detecting certain substances in decomposing tissues. ${ }^{67}$ Qualitative as well as quantitative analysis of traces of chemical substances recovered from maggots present on extensively decomposed bodies have well-documented applications in forensic investigations. ${ }^{68}$ Reports of suicide cases consisting of forensic investigations for detection of traces of phenobarbital ${ }^{69}$ and cocaine ${ }^{70}$ have further highlighted the potential of entomological analysis for detection of antemortem drugs and toxins. The growth rates of maggots feeding on corpses overdosed with certain drugs may be accelerated ${ }^{70,71}$ (eg: cocaine, heroin or morphine) or retarded ${ }^{72}$ (e.g.: organophosphate malathion) or even cease completely when they are killed ${ }^{73}$ (eg: kerosene, gasoline, chloroform, ether). Therefore, the possibility of underestimation when presence of morphine in the corpse is not considered while calculating the PMI cannot be overlooked. ${ }^{74}$

The advantage offered by the toxicological analysis of Diptera larvae feeding on carrion is that it can provide valuable information about antemortem circumstances and location of death for periods as long as 10 weeks post-mortem. ${ }^{67}$ An example of this utility of toxicological analysis was the demonstration of low mercury concentration in Diptera larvae from a decomposing body discovered in an area affected by mercury pollution, indicating that the body was not from the area where it was located it was found. ${ }^{75}$ The toxicological findings guided the police investigators to certain areas that were relatively free of mercury pollution which led to successful tracking of the victim and resolved the case. Drugs and toxins may also be identified through empty pupal cases left behind or excreted material from beetles, several years after the death. ${ }^{76,77}$ Therefore, adequate toxicological investigations must be undertaken for a comprehensive drug screening in bodies whenever there is a suspected relevance of drugs with death. ${ }^{78}$

\section{Molecular Techniques in Forensic Entomology}

Since blowflies are most important in forensic entomological investigations, abundant genetic research pertaining to their analysis has been conducted. Most of them focus on mitochondrial encoded the gene for cytochrome oxidase. ${ }^{79}$ The polymerase chain reaction technique enables amplification of the suitable regions of the genome, allowing identification of arthropods in cases where the morphologically unsuitable or fragmented body parts of insects are obtained. ${ }^{80}$ The technique is also particularly advantageous in terms of efficiency as compared to more time-consuming rearing of the larvae to adults for identification which tend to delay investigatory procedures or fail at times. ${ }^{7}$ Identification of genetic material of victim from within the gastrointestinal tract of maggots is yet another molecular implication of Forensic Entomology. ${ }^{81}$ This approach is particularly preferable in cases when the source of food for maggots is irresolute for instance, when only maggots are found at the scene of a crime without any corpse or when multiple food sources are present. In such cases, identifying individual-specific DNA in maggots can associate them with a specific corpse. ${ }^{82}$

However, the advanced molecular techniques are not free of limitations in that apart from their frequent unfeasibility and unavailability in various settings such as rural areas, closely related species may show identical sequences or even reflect hybridization. ${ }^{83}$ To overcome such situations, alternative techniques such as Restriction Fragment Length Polymorphism analysis have been suggested that restrict the analysis to only a selected area of a nucleotide sequence which may aid in eliminating false inclusions. ${ }^{84}$

\section{Possible Role of Forensic Odontologists}

The fact that maggots first appear near the oral cavity of a corpse highlights the potential role of a forensic odontologist in entomological investigations. ${ }^{48}$ Infestation of maggots or Diptera larvae can pervade in the wounds or oral cavity of living humans or animals as well, suggesting an antemortem period of neglect. ${ }^{85}$ Such neglect may occur in cases of abandoned infants, ${ }^{86}$ elderly in nursing homes, homelessness, alcoholism, bedridden individuals. ${ }^{87}$ The extent of the duration of antemortem neglect can be estimated by the age determination of these infested maggots. ${ }^{88}$ This possibility of antemortem infestation by flies must not be overlooked when estimating PMI for suspected cases of neglect. Conversely, false perception of an antemortem infestation can occur even when the arthropods arrive on the body after death. The insight offered by a forensic odontologist in ascertaining the 
periodontal health and overall oral hygiene status could provide clarity in terms of antemortem neglect. Blowfly evidence from human saliva along with toxicological analysis of human saliva can further be correlated in suspected cases. ${ }^{89}$

\section{Forensic Entomology in Court of Law}

The integration of forensic evidence in a medicocriminal investigation requires the presentation of characteristic morphology, various physical parameters involved and composition of arthropod species identified on a corpse. It has been pointed out that the subdivisions used to described insects associated with a decomposing corpse are ambiguous and may not be clearly distinguishable in practice..$^{90}$ Nevertheless, the description of these stages provides a valuable chronological reference for explaining the results to a jury. Furthermore, the circumstances surrounding the dead body in every case are different which may significantly alter the final values derived from entomological data. Therefore, to ensure that the entomological data obtained from a crime scene is reliable, reproducible, and valid, certain standards and guidelines have been established which would provide quality assurance and accreditation of Forensic Entomology in the courtroom. ${ }^{91}$

Several authors have formulated and suggested protocols for collecting and presenting entomological evidence. A guide for the collection of entomological evidence from corpses was provided by Lord \& Burger in $1983,{ }^{92}$ which was later elaborated with the addition of guidelines for subsequent sample handling in a compendious Forensic Entomology Manual authored by Smith. ${ }^{21}$ A comprehensive checklist for crime-scene entomologists and autopsy pathologists was developed by Catts \& Haskell in 1991 in a manual entitled 'Entomology and Death: a procedural guide'. ${ }^{25}$ However, the standards may vary for jurisdiction systems across different geographical areas since each location has its own distinct environmental conditions.

Entomologists may not always have the opportunity to be present at the scene of crime owing to certain conditions. At times, useful evidence may go unnoticed at the crime scene due to lack of training or awareness about what to look for or retrieving the entomological evidence. ${ }^{92}$ This problem should be tackled in two stages. First, a specific certified curriculum training program for reinforcement of the credibility of forensic entomologists should be established. Secondly, the forensic entomologists can arrange trial drills with local death-scene investigators for the collection of entomological data from the crime scene. ${ }^{93}$ Forensic investigations involve coordination between personnel from various fields such as law-enforcement agencies, medical examiners, entomologists, pathologists, technicians, botanists, anthropologists to ensure a proper understanding of the evidence recorded at the crime scene and during autopsy. ${ }^{46}$

\section{Conclusion}

Forensic entomology has proved its utility in resolving numerous cases of medico-criminal and toxicological forensic investigations throughout the years. Even so, it cannot be denied that analysis of entomological evidence in itself presents with certain limitations owing to circumstances surrounding the corpse, such as submergence of corpse or loss of morphology of maggots. Undoubtedly, recent advances in molecular techniques and generous efforts of researchers are able to provide a solution to these existing problems, consequently widening the scope with a renewed interest in the field. Need for developing standard entomological data references specifically to various geographical locations necessitate further research throughout the globe. Emphasis should be laid on the inclusion of a forensic entomologist in the crime-scene investigation team to gain a reliable understanding of the complex interactions between the environment and the corpse and collection of specimens that could be perplexing for other forensic personnel. Overall, the discipline of Forensic Entomology needs further exploration and research to tackle the existing problems in the field using modernday advancements in order to establish global standards for entomological evidence.

\section{REFERENCES}

1. Anderson GS, Cervenka VJ, Haglund W, Sorg M. Insects associated with the body: their use and analyses. In: Haglund WD, Sorg MH. Advances in forensic taphonomy: method, theory, and archaeological perspectives. CRC Press, New York. 2002;173200.

2. Budd GE, Telford MJ. The origin and evolution of arthropods. Nature. 2009 Feb;457(7231):812-817.

3. Illingworth JF. Insects attracted to carrion in Southern California. InProc Hawaii Entomol Soc 1926;6:397-401.

4. Benecke M. A brief history of forensic entomology. For Sci Int. 2001 Aug 15;120(1):2-14.

5. Keh B. Scope and applications of forensic entomology. Annual review of entomology. 1985 Jan;30(1):137-154.

6. Lord W, Stevenson J. Directory of Forensic Entomologists. Washington DC: Am. Reg. Prof. Entomol. 2nd ed.1986:pp-42

7. Amendt J, Richards CS, Campobasso CP, Zehner R, Hall MJ. Forensic entomology: applications and limitations. Forensic science, medicine, and pathology. 2011 Dec;7(4):379-392.

8. Greenberg B, Kunich JC. Entomology and the law: flies as forensic indicators. Cambridge University Press, Cambridge 2002.

9. McKnight B. The Washing Away of Wrongs: Forensic Medicine in Thirteenth-Century China. Ann Arbor: Univ. Michigan. 1981:pp-181.

10. Orfila MJ. Traité de médecine légale. Labé; 1848.

11. Bergeret M. Infanticide, momification naturelle du cadavre. Ann Hyg Publique Med Leg. 1855;4:442-452.

12. F.L. Krahmer, Handbuch der gerichtlichen Medizin fur Aerzte und Juristen, Schwetschke \& Sohn, Braunschweig, 1857, p. 625.

13. Motter MG. A contribution to the study of the fauna of the grave. A study of on hundred and fifty disinterments, with some additional experimental observations. Journal of the New York Entomological Society. 1898 Dec 1;6(4):201-231.

14. Hofmann, Observation de larves de Dipte'res sur des cadavres exhume's (Observation on Diptera larvae on exhumated corpses), C.R. Se'ances Soc. Ent. Bel. 74 (1886) 131-132

15. Megnin JP. La faune des cadavres Encyclopedie Scientifique des Aide-Memoire. Paris: Masson, Gauthier-Villars et Fils; 1894. p. 1-224. 
16. Hunziker. Observations during the exhumation on the graveyards of Basel. Under special consideration on the fauna and flora of the graves), Frankf.Z. Pathol. 22 (1919) 147-207

17. Henge C, Madea B, Knight B, Nokes L, Krompecher T. The estimation of the time since death in the early postmortal interval. Arnold, London. 1995.

18. Early M, Goff ML. Arthropod succession patterns in exposed carrion on the island of O'ahu, Hawaiian Islands, USA. 1. Med. Entomol. 1986;23:520-531

19. Catts EP. Problems in estimating the post-mortem interval in death investigations. J Agric Entomol. 1992;9:245-255.

20. Early M, Goff ML. Arthropod succession patterns in exposed carrion on the island of O'ahu, Hawaiian Islands, USA. Journal of Medical Entomology. 1986 Sep 19;23(5):520-531.

21. Smith, K. G. V. A Manual of Forensic Entomology. London: British Museum (Natural History), Comstock. 1986:pp-205.

22. Nainis I, Marchenko M, Kazak A. A calculation method for estimating by entomofauna the period during which the body had remained in the place where it was found. Sud. Med. Ekspert. 1982;25:21-23.

23. Goff M. Gamasid mites as potential indicators of post-mortem interval. in Acarology, ed. G. P. Channabasavanna, C. A. Viraktamath,New Delhi: Oxford \& IBH. 1989;1:443-450.

24. Goodbrod JR, Goff ML. Effects of larval population density on rates of development and interactions between two species of Chrysomya (Diptera: Calliphoridae) in laboratory culture. Journal of Medical Entomology. 1990 May 1;27(3):338-343.

25. Catts EP, Haskell NH. Entomology and death: a procedure guide. Clemson, SC: Joyce's Print Shop. 1991. pp. 180

26. Bourel B, Callet B, Hédouin V, Gosset D. Flies eggs: a new method for the estimation of short-term post-mortem interval? Forensic science international. 2003 Jul 29;135(1):27-34.

27. Kamal AS. Comparative study of thirteen species of sarcosaprophagous Calliphoridae and Sarcophagidae (Diptera) I. Bionomics. Annals of the Entomological Society of America. 1958 May 1;51(3):261-71.

28. Williams H. A model for aging of fly larvae in Forensic Entomology. Forensic Sci. Int. 1984;25:191-99

29. Wells JD, LaMotte LR. Estimating maggot age from weight using inverse prediction. J Forensic Sci. 1995;40:585-590

30. Adams ZJO, Hall MJR. Methods used for the killing and preservation of blowfly larvae, and their effect on post-mortem larval length. Forensic Sci Int. 2003;138:50-61.

31. Greenberg B. Nocturnal oviposition behaviour of blow flies (Diptera: Calliphoridae). J Med Entomol. 1990;27:807-810.

32. Amendt J, Campobasso CP, Gaudry E, Reiter C, LeBlanc HN, Hall MJ. Best practice in forensic entomology — standards and guidelines. International journal of legal medicine. 2007 Mar;121(2):90-104.

33. Amendt J, Krettek R, Niess C, Zehner R, Bratzke H. Forensic entomology in Germany. Forensic Science International. 2000 Sep 11;113(1-3):309-14.

34. Schoenly K, Goff ML, Wells JD, Lord WD Quantifying statistical uncertainty in succession-based entomological estimates of the post-mortem interval in death scene investigations: a simulation study. Am Entomol. 1996;42:106-112

35. ComabyB. 1974. Carrion reduction by animals in contrasting tropical habitats. Biotropica. 6:51-63

36. Thomas D, Chen A. Age determination in adult screw-worms (Diptera: Calliphoridae) by pteridine levels. J. Econ. Entomol. 1989;82:1140-44
37. Villet MH, Richards CS, Midgley JM. Contemporary precision, bias and accuracy of minimum post-mortem intervals estimated using development of carrion-feeding insects. In: Amendt J, Campobasso CP, Goff ML, Grassberger M, editors. Current concepts in Forensic Entomology. Dordrecht: Springer; 2010. p.109-137.

38. Baskerville GL, Emin P. Rapid estimation of heat accumulation from maximum and minimum temperatures. Ecology. 1969;50:514-517

39. Higley LG, Haskel NH. Insect development and Forensic Entomology. In: Byrd JH, Castner JL, editors. Forensic Entomology - the utility of arthropods in legal investigations. Boca Raton: CRC Press. 2010. p. 389-405.

40. Zehner R, Amendt J. Boehme P: gene expression analysis as a tool for age estimation of blowfly pupae. For Sci Int Genet Suppl. 2009;2:292-293

41. Tarone AM, Kimberley C, Jennings MS, Foran DR. Aging blow fly eggs using gene expression: a feasibility study. J Forensic Sci. 2007;52:1350-1354.

42. Mann RW, Bass WM, Meadows L. Time since death and decomposition of the human body: variables and observations in case and experimental field studies. Journal of Forensic Science. 1990 Jan 1;35(1):103-111.

43. Rodriguez W, Bass W. Insect activity and its relationship to decay rates of human cadavers in east Tennessee. J. Forensic Sci. 1983;28:423-432.

44. Morovic-Budak A. Experiences in the process of putrefaction in corpses buried in earth. Med Sci Law.1965;5:40-43

45. Williams H, Richardson AM. Growth energetics in relation to temperature for larvae of four species of necrophagous flies (Diptera: Calliphoridae). Australian Journal of Ecology. 1984 Jun;9(2):141-152.

46. Campobasso CP, Introna F. The forensic entomologist in the context of the forensic pathologist's role. Forensic Sci Int. 2001; 120:132-139.

47. Giertsen JC. Drowning. In: C. G. Tedeschi, W. G. Eckert, L. G. Tedeschi. Forensic medicine, a study in trauma and environmental hazards, Philadelphia, Saunder. 1977:1324.

48. Amendt J, Krettek R, Zehner R. Forensic entomology. Naturwissenschaften. 2004 Feb;91(2):51-65.49.

49. Littlejohn, H. 1925. Forensic Medicine. pp. 1-1 1 , 76. London: Churchill. pp. 285.

50. Avila FW, Goff ML. Arthropod succession patterns onto burnt carrion in two contrasting habitats in the Hawaiian Islands. Journal of forensic science. 1998 May 1;43(3):581-586.

51. Fuller ME. The insect inhabitants of carrion: a study in animal ecology. Aust. Counc. Sci. Ind. Res. Bull. 1934; 82. pp 62.

52. Goff ML. Problems in estimation of post-mortem interval resulting from wrapping of the corpse: a case study from Hawaii. Journal of Agricultural Entomology. 1992 Oct 1;9(4):237243.

53. Campobasso CP, Di Vella G, Introna F. Factors affecting decomposition and Diptera colonization. Forensic Sci Int.2001;120:18-27.

54. VanLaerhoven SL. Ecological theory and its application in Forensic Entomology. In: Byrd JH, Castner JL, editors. Forensic Entomology-the utility of arthropods in legal investigations. Boca Raton: CRC Press; 2010. pp. 493-518.

55. UbelakerD, Willey P.Complexity in Arikara mortuary practice. Plains Anthropol. 1978;23(79):69-74.

56. Merritt RW, Wallace JR. The role of aquatic insects in forensic 
investigations. Forensic Entomology: The utility of arthropods in legal investigations. 2001:177-222.

57. Simpson K. Forensic Medicine.London: Arnold. 6th ed. 1969; pp 361.

58. Nom MS. Demodex folliculorum. Incidence, regional distribution, pathogenicity. Dan. Med. Bull. 1971;18:14-17

59. Arutjunov, A. M. The use of entomological data in a forensic medicine examination. Sud.-Med. Eksperl. 1963;6:51-52

60. Johnson DW, Cockburn AF. Insect identification using DNA probes. Arch. Biochem. Physiol. 1992;82:113-117.

61. Catts EP, Goff ML. Forensic entomology in criminal investigations. Annual review of Entomology. 1992 Jan;37(1):253-272.

62. Webb J, Loomis R, Madon M, BennettS, GreenG. The chigger species Eutrombicula belkini Gould (Acari: Trombiculidae) as a forensic tool in a homicide investigation in Ventura County, California. Bull. Soc. Vector Ecol. 1983;8:141-146

63. Campobasso CP, Marchetti D, Introna F, Colonna MF. Postmortem artifacts made by ants and the effect of ant activity on decompositional rates. Am J Forensic Med Pathol. 2009;30:84-87.

64. Lucas A. Forensic Chemistry and Scientific Criminal Investigation. London: Arnold. 4th ed. 1945. 340 pp.

65. Grace J, Wood D, Grunbaum, B. Effect of Argentine ant contamination on ABO blood typing of human saliva samples. Bull. Entomol Soc Am. 1986;32:147-149.

66. Lord, W. D, Rodriguez, W. C. Forensic Entomology: the use of insects in the investigation of homicide and untimely death. Prosecutor. 1989;22:41-48.

67. Kintz P, Godelar B, Tracqui A, Mangin P, Lugnier AA, Chaumont AJ. Fly larvae: a new toxicological method of investigation in forensic medicine. J For Sci. 1990 Jan 1;35(1):204-207.

68. Introna F, Dico CL, Caplan YH, Smialek JE. Opiate analysis in cadaveric blowfly larvae as an indicator of narcotic intoxication. J For Sci. 1990 Jan 1;35(1):118-122.

69. Beyer JC, Enos WF, Stajić M. Drug identification through analysis of maggots. J For Sci. 1980 Apr 1;25(2):411-412.

70. Goff ML, Omori AI, Goodbrod JR. Effect of cocaine in tissues on the rate of development of Boettcherisca peregrina (Diptera: Sarcophagidae). J Med Entomol. 1989;26:91-93.

71. Goff ML, Brown WA, Hewadikaram KA, Omori AI. Effects of heroin in decomposing tissues on the development rate of Boettcherisca peregrina (Diptera: Sarcophagidae) and implications of this effect on estimation of post-mortem intervals using arthropod development patterns. J Forensic Sci. 1991;36:537-542.

72. Gunatilake K, Goff LL. Detection of organophosphate poisoning in a putrefying body by analyzing arthropod larvae. Journal of Forensic Science. 1989 May 1;34(3):714-716.

73. Rivers R. Embalming artifacts. J. Forensic Sci.1978;23:531-535.

74. Bourel B, Hodouin V, Martin-Bouyer L, Becart A, Tournel $\mathrm{G}$, et al. Effects of morphine in decomposing bodies on the development of Lucilia sericata (Diptera: Calliphoridae). J Forensic Sci.1991;44:354-358.

75. Nuorteva P, Nuorteva SL. The fate of mercury in sarcosaprophagous flies and in insects eating them. Ambio. 1982;11:34-37.

76. Pien K, Laloup M, Pipeleers-Marichal M, et al. Toxicological dataand growth characteristics of single post-feeding larvae and puparia of Calliphora vicina (Diptera: Calliphoridae) obtained from a controlled nordiazepam study. Int J Leg Med. 2004;118:190-193.

77. Miller ML, Lord WD, Goff ML, Donnelly B, McDonough ET, Alexis JC. Isolation of amitrptyline and nortriptyline from fly puparia (Phoridae) and beetle exuviae (Dermestidae) associated with mummified human remains. J Forensic Sci. 1994;39:13051313.

78. Levine B, Golle M, Smialek JE. An unusual drug death involving maggots. Am J Forensic Med Pathol. 2000;21:59-61.

79. Wells JD, Introna F, Di Vella G, Campobasso CP, Hayes J, Sperling FA. Human and insect mitochondrial DNA analysis from maggots. J Forensic Sci. 2001;46:685-687.

80. Wells JD, Stevens JR. Application of DNA-based methods in Forensic Entomology. Annu. Rev. Entomol. 2008 Jan 7;53:103120.

81. Campobasso CP, Linville JG, Wells JD, Introna F. Forensic genetic analysis of insect gut contents. Am J Forensic Med Pathol. 2005;26:161-165.

82. Zehner R, Amendt J, Schütt S, Sauer S, Krettek R, Povolny' D. Genetic identification of forensically important flesh flies (Diptera : Sarcophagidae). Int J Leg Med. 2004;118:245-247.

83. Stevens JR, Wall R, Wells JD. Paraphyly in Hawaiian hybrid blowfly populations and the evolutionary history of anthropophilic species. Insect Mol Biol. 2002;11:141-148.

84. Wells JD, Wall R, Stevens JR. Phylogenetic analysis of forensically important Lucilia flies based on cytochrome oxidase I sequence: a cautionary tale for forensic species determination. Int J Leg Med. 2007;121:229-233.

85. Droma EB, Wilamowski A, Schnur H, Yarom N, Scheuer E, Schwartz E. Oral myiasis: a case report and literature review. Oral Surgery, Oral Medicine, Oral Pathology, Oral Radiology, and Endodontology. 2007 Jan 1;103(1):92-96.

86. Goff ML, Charbonneau S, Sullivan W. Presence of fecal material in diapers as a potential source of error in estimations of postmortem interval using arthropod development rates. Journal of Forensic Science. 1991 Sep 1;36(5):1603-1606.

87. Sherman RA. Wound myiasis in urban and suburban United States. Arch Intern Med. 2000;160:2004-2014.

88. Benecke M. Neglect of the elderly: Cases and Considerations. In: Proceedings of the Meeting of the European Association of Forensic Entomologist, Frankfurt 2003 Apr (pp. 2-5).

89. Durdle A, Mitchell RJ, van Oorschot RA. The use of forensic tests to distinguish blowfly artifacts from human blood, semen, and saliva. J For Sci. 2015 Mar;60(2):468-470.

90. Schoenly K, Reid W. Dynamics of heterotrophic succession in carrion arthropod assemblages: discrete series or a continuum of change? Oecologia.1987;73:192-202.

91. 91. VanLaerhoven SL. Ecological theory and its application in forensic entomology. In: Byrd JH, Castner JL, editors. Forensic entomology-the utility of arthropods in legal investigations. Boca Raton: CRC Press; 2010. p. 493-518.

92. Lord WD, Burger JF (1983) Collection and preservation of forensically important entomological materials. J For Sci.1983;28:936-944

93. Haskell NH, Williams RE. Collection of entomological evidence at the death scene. Entomology \& Death: A Procedural Guide. 1990:82-97. 